\title{
umjember
}

\section{Faktor-Faktor yang Memengaruhi Perilaku Proses Pencarian Informasi Berbasis Digital oleh Penyuluh Pertanian Provinsi Jawa Tengah}

\section{Factors Influencing the Behavior of Digital-Based Information Seeking Process by Agricultural Extension in Central Java Province}

Mohamad Triaji, Dwiningtyas Padmaningrum, Sapja Anantanyu

Universitas Sebelas Maret Surakarta

email: mtriaji.id@gmail.com,dwiningtyas_p@staff.uns.ac.id, sap_anan@yahoo.com

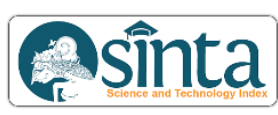

Corresponding Author: Mohamad Triaji, Universitas Sebelas Maret, mtriaji.id@gmail.com

\begin{abstract}
ABSTRAK
Perkembangan pesat dunia digital memberikan tantangan bagi penyuluh dalam mencari, mengakses, dan memanfaatkan informasi. Penyuluh pertanian dituntut terampil dalam menggunakan perangkat digital untuk melakukan pencarian Informasi dalam memenuhi kebutuhan Informasi petani. Literasi digital menjadi kunci keberhasilan penyuluh dalam menyampaikan Informasi kepada petani. Penelitian ini bertujuan untuk menganalisis pengaruh faktor-faktor pembentuk perilaku pencarian Informasi terhadap perilaku pencarian Informasi berbasis digital oleh penyuluh pertanian. Metode penelitian yang digunakan adalah metode kuantitatif dengan analisis data menggunakan regresi linier berganda. Teknik penentuan sampel yang digunakan adalah non-probability sampling dengan jenis accidental sampling. Penelitian ini mengambil sampel 155 responden yang merupakan penyuluh pertanian anggota PERHIPTANI di wilayah Provinsi Jawa Tengah. Hasil penelitian menunjukkan bahwa kemampuan literasi digital, tingkat pendidikan formal, dan pengalaman kerja memiliki pengaruh yang signifikan, sedangkan usia dan tingkat penggunaan media tidak memiliki pengaruh signifikan terhadap perilaku pencarian informasi berbasis digital oleh penyuluh pertanian.
\end{abstract}

Kata kunci: Literasi Digital; Penyuluh Pertanian; Perilaku Pencarian Informasi

ABSTRACT
Rapid development of digital word presents a challenge for extension agents to found, accessed, and utilized information. Extension agriculture agents are required to be skilled in using digital tools to search information in fulfilled farmer's information needs. Digital literacy is the key success of extension agriculture agents in convey information to farmers. This study aims to analyze the effect of factors in information seeking behavior on digital-based information seeking behavior by extension agriculture agents. Research method used quantitative method with data analysis using multiple linear regression. Sampling technique used nonprobability sampling with accidental sampling type. This study took 155 respondents who were extension agriculture agents of PERHIPTANI in the Central Java Province. Results showed that digital literacy skills, formal education, and work experience have significant effect, while age and level of media use does not have significant effect on digital-based information seeking behavior by agricultural extension agents.

Keywords: Agriculture Extension; Digital Literacy; Information Seeking Behavior

\section{PENDAHULUAN}

Indonesia merupakan negara dengan jumlah masyarakat pengguna internet terbesar di dunia. Hasil riset yang dilakukan oleh Asosiasi Penyelenggara Jasa Internet Indonesia (APJII) Tahun 2018 menunjukkan ada sebanyak 171,71 juta jiwa atau sekitar 64,8 persen yang sudah terhubung ke internet (APJII, 2018). Perkembangan pesat dunia digital ini tidak hanya berdampak sisi positif melainkan akan memberikan tantangan tersendiri bagi masyarakat Indonesia. Perkembangan pesat tersebut menuntut kemampuan individu, khususnya dalam memanfaatkan perangkat digital seperti 
komputer, laptop, gadget, dan perangkat TIK lainnya. Kemampuan individu dalam memanfaatkan perangkat digital perlu didukung dengan tingkat literasi yang memadai. Salah satu perkembangan literasi yang saat ini menjadi hal penting untuk dipahami pada era digital adalah literasi digital. Hal tersebut dikarenakan masyarakat pada era digital dituntut dapat menerapkan literasi digital secara komprehensif. Literasi digital merupakan keterampilan seseorang dalam menggunakan media digital untuk mendapatkan informasi dan berkomunikasi dengan beretika dan dapat dipertanggungjawabkan (Gilster, 1997). Literasi digital dapat membantu seseorang meningkatkan kemampuan untuk memenuhi kebutuhan informasi. Salah satu profesi yang penting untuk memahami dan meningkatkan literasi digital adalah penyuluh pertanian.

Penyuluh pertanian berperan penting dalam menyebarkan informasi yang berkaitan dengan upaya perbaikan cara-cara bertani dan berusahatani (Mardikanto, 2010). Tuntutan penyuluh untuk memanfaatkan teknologi digital diatur sesuai Peraturan Menteri Pertanian Republik Indonesia Nomor: 03/Permentan/SM.200/1/2018 yang menyatakan bahwa materi penyuluhan pertanian harus memuat unsur peningkatan ilmu pengetahuan, teknologi dan informasi. Tuntutan tersebut secara tidak langsung mewajibkan penyuluh untuk mencari informasi dengan cepat dan tepat serta dapat mengikuti perkembangan teknologi dan informasi secara global melalui pemanfaatan TIK. Penyuluh pertanian dan informasi merupakan dua hal yang tidak dapat dipisahkan (Rasmira et al., 2019). Penyuluh pertanian membutuhkan kemampuan untuk mencari informasi yang tepat demi menunjang kegiatan penyuluhan pertanian ke petani.

Penyuluh pertanian perlu memiliki keterampilan literasi digital dalam menjalankan tugas penyuluh (Eisenberg, 2008). Literasi digital menjadi kunci keberhasilan penyuluh dalam menyampaikan informasi yang telah tersaring kepada petani dan akan meningkatkan kepercayaan petani kepada penyuluh jika dapat menggunakan perangkat digital dan teknologi informasi dengan baik (Singh, 2018). Besarnya tantangan yang dihadapi penyuluh di tengah perkembangan pesat media digital dan teknologi informasi menuntut diperlukannya penelitian yang lebih mendalam dan komprehensif terhadap literasi digital penyuluh pertanian. Hasil penelitian terkait literasi digital ini diharapkan dapat menjadi informasi tambahan terkait pentingnya literasi digital untuk penyuluh pertanian dalam proses mewujudkan pembangunan pertanian. Oleh karena itu, diperlukan sebuah kajian mendalam untuk mengetahui bagaimana pengaruh literasi digital terhadap perilaku pencarian informasi yang dilakukan penyuluh pertanian untuk memenuhi kebutuhan informasi dalam menunjang kegiatan penyuluhan pertanian terutama di era digital saat ini.

Berdasarkan latar belakang tersebut, tujuan dari penelitian ini adalah menganalisis pengaruh faktor-faktor pembentuk perilaku proses pencarian informasi terhadap perilaku proses pencarian informasi berbasis digital oleh penyuluh pertanian.

\section{Desain Penelitian}

\section{METODE}

Metode dasar yang digunakan dalam penelitian ini adalah metode kuantitatif. Metode kuantitatif yaitu suatu metode untuk menguji teori-teori tertentu dengan cara meneliti hubungan antar variabel

(Juliansyah, 2013). Teknik penelitian menggunakan teknik survei, yaitu penelitian dengan cara pengambilan sampel dari suatu populasi dan menggunakan kuesioner sebagai alat pengumpul data (Singarimbun \& Efendi, 2008). Penelitian kuantitatif ini menggunakan pendekatan regresi linier berganda. Regresi linier berganda adalah penelitian untuk memprediksikan seberapa jauh perubahan nilai variabel dependen, apabila nilai variabel independen dimanipulasi atau dinaikturunkan.

\section{Lokasi Penelitian}

Penetapan lokasi penelitian ditentukan secara sengaja (purposive) berdasarkan pertimbangan tertentu dan diambil berdasarkan tujuan penelitian (Sugiyono, 2013). Lokasi penelitian dalam penelitian ini yaitu tersebar di 31 Kabupaten/Kota pada Provinsi Jawa Tengah. Alasan Provinsi Jawa Tengah dijadikan lokasi penelitian yaitu dengan pertimbangan bahwa wilayah tersebut memiliki jumlah anggota Perhimpunan Penyuluh Pertanian Indonesia (PERHIPTANI) terbanyak dibandingkan wilayah provinsi lain. 


\section{Populasi dan Sampel Penelitian}

Populasi dalam penelitian ini adalah seluruh penyuluh pertanian PNS yang merupakan anggota PERHIPTANI Wilayah Jawa Tengah dengan jumlah 2.631 penyuluh. Teknik penentuan sampel yang digunakan adalah non-probability sampling dengan jenis sampling yang digunakan yaitu purposive sampling. Purposive sampling merupakan teknik pengambilan sampel berdasarkan pertimbangan atau kriteria yang fokus pada tujuan tertentu (Arikunto, 2002). Kriteria responden pada penelitian ini yaitu penyuluh pertanian PNS anggota PERHIPTANI Jawa Tengah berusia 30-60 Tahun dan memiliki setidaknya 1 perangkat digital yang digunakan secara aktif dalam kegiatan pencarian informasi di internet. Jumlah responden pada penelitian ini adalah 155 responden.

\section{Metode Pengumpulan Data}

Metode pengumpulan data yang digunakan yaitu kuesioner (angket), wawancara, dan dokumentasi. Pengumpulan data dilakukan dengan membagikan kuesioner online melalui Google form di link bit.ly/2Lg9Dw2. Kuesioner dibagikan melalui media sosial WhatsApp yang disampaikan secara pribadi kepada ketua DPD masing-masing kabupaten/kota di Jawa Tengah.

\section{Metode Analisis Data}

Analisis deskriptif bertujuan untuk mendeskripsikan data yang telah diperoleh dari masingmasing variabel sehingga menjadi sebuah informasi atau gambaran umum responden. Analisis deskriptif pada penelitian ini berupa penyajian data mengenai usia, jenis kelamin, lokasi geografis, pendidikan formal, jumlah desa binaan, dan jumlah kepemilikan perangkat digital yang disajikan melalui tabel maupun grafik.

Pengukuran variabel kemampuan literasi digital $\left(\mathrm{X}_{1}\right)$ diukur menggunakan beberapa indikator yang diturunkan dari dimensi variabel. Dimensi variabel kemampuan literasi digital terdiri dari dimensi kemampuan informasi dan literasi data serta kemampuan komunikasi dan kolaborasi. Pengukuran variabel kemampuan literasi digital (X1) dapat dijelaskan pada Tabel 1.

Tabel 1. Pengukuran Variabel Kemampuan Literasi Digital

\begin{tabular}{|c|c|c|c|c|}
\hline Dimensi & Indikator & Kriteria & $\begin{array}{c}\text { Kategori } \\
\text { (Skor) }\end{array}$ & Butir \\
\hline $\begin{array}{l}\text { 1. Kemampuan } \\
\text { Informasi } \\
\text { dan Literasi } \\
\text { Data } \\
\text { (Information } \\
\text { and Data } \\
\text { Literacy) }\end{array}$ & $\begin{array}{l}\text { Mengidentifikasi } \\
\text { dan eksplorasi } \\
\text { materi } \\
\text { penyuluhan } \\
\text { pertanian }\end{array}$ & $\begin{array}{l}\text { - Tidak mampu } \\
\text { mengidentifikasi dan } \\
\text { eksplorasi materi } \\
\text { - Kurang mampu } \\
\text { mengidentifikasi dan } \\
\text { eksplorasi materi } \\
\text { - Mampu } \\
\text { mengidentifikasi dan } \\
\text { eksplorasi materi } \\
\text { - Sangat mampu } \\
\text { mengidentifikasi dan } \\
\text { eksplorasi materi }\end{array}$ & $\begin{array}{l}\text { - Rendah (1) } \\
\text { - Sedang (2) } \\
\text { - Tinggi (3) } \\
\text { - Sangat } \\
\text { Tinggi (4) }\end{array}$ & $\begin{array}{c}12,13, \\
14,15,16\end{array}$ \\
\hline & $\begin{array}{l}\text { Mengolah materi } \\
\text { penyuluhan } \\
\text { pertanian }\end{array}$ & $\begin{array}{l}\text { - Tidak mampu mengolah } \\
\text { materi } \\
\text { - Kurang mampu } \\
\text { mengolah materi } \\
\text { - Mampu mengolah } \\
\text { materi } \\
\text { - Sangat mampu } \\
\text { mengolah materi }\end{array}$ & $\begin{array}{l}\text { - Rendah (1) } \\
\text { - Sedang (2) } \\
\text { - Tinggi (3) } \\
\text { - Sangat } \\
\text { Tinggi (4) }\end{array}$ & $\begin{array}{l}17,18 \\
19,20\end{array}$ \\
\hline
\end{tabular}




\begin{tabular}{|c|c|c|c|c|}
\hline \multirow[t]{2}{*}{ Dimensi } & Indikator & Kriteria & $\begin{array}{c}\text { Kategori } \\
\text { (Skor) }\end{array}$ & Butir \\
\hline & $\begin{array}{l}\text { Mengevaluasi } \\
\text { materi } \\
\text { penyuluhan } \\
\text { pertanian }\end{array}$ & $\begin{array}{lc}\text { - Tidak mampu } & \text { materi } \\
\text { mengevaluasi materi mampu } \\
\text { - Kurang materi } \\
\text { mengevaluasi mati } \\
\text { - Mampu mengevaluasi } \\
\text { materi } \\
\text { - Sangat } \\
\text { mengevaluasi materi }\end{array}$ & $\begin{array}{l}\text { - Rendah (1) } \\
\text { - Sedang (2) } \\
\text { - Tinggi (3) } \\
\text { - Sangat } \\
\text { Tinggi (4) }\end{array}$ & $21,22,23$ \\
\hline \multirow[t]{4}{*}{ 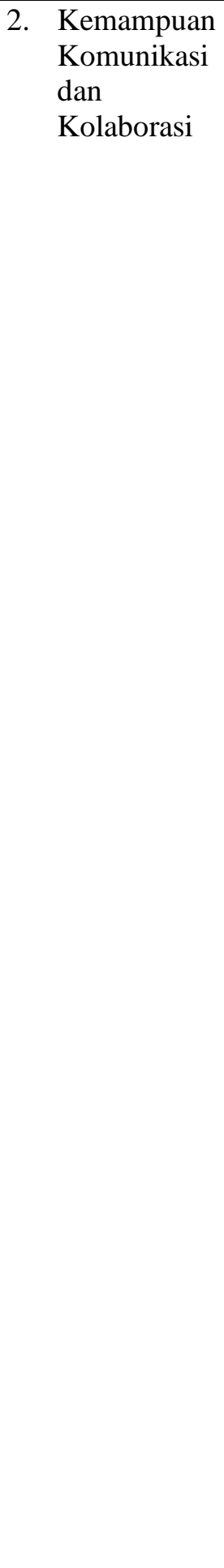 } & $\begin{array}{l}\text { Mendiskusikan } \\
\text { materi } \\
\text { penyuluhan } \\
\text { pertanian di grup } \\
\text { online }\end{array}$ & $\begin{array}{l}\text { - } \text { Tidak aktif } \\
\text { mendiskusikan materi di } \\
\text { grup online } \\
\text { - Kurang aktif } \\
\text { mendiskusikan materi di } \\
\text { grup online } \\
\text { - Aktif mendiskusikan } \\
\text { materi di grup online } \\
\text { - Sangat aktif } \\
\text { mendiskusikan materi di } \\
\text { grup online }\end{array}$ & $\begin{array}{l}\text { - Rendah (1) } \\
\text { - Sedang (2) } \\
\text { - Tinggi (3) } \\
\text { - Sangat } \\
\text { Tinggi (4) }\end{array}$ & 24,25 \\
\hline & $\begin{array}{l}\text { Membagikan } \\
\text { konten materi } \\
\text { penyuluhan } \\
\text { pertanian melalui } \\
\text { media sosial }\end{array}$ & 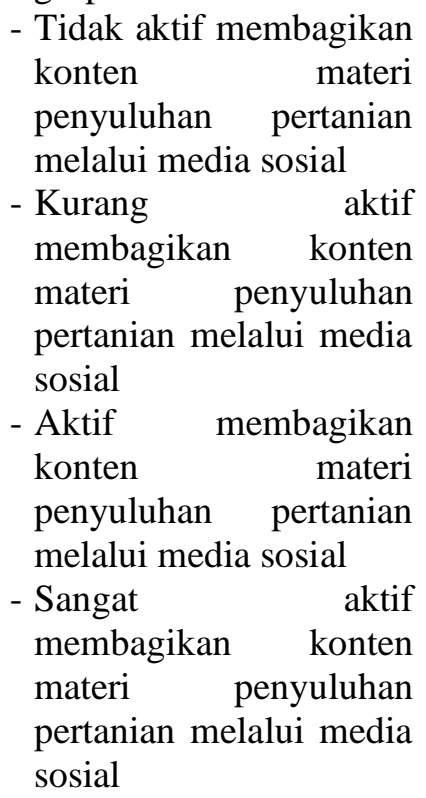 & $\begin{array}{l}\text { - Rendah (1) } \\
\text { - Sedang (2) } \\
\text { - Tinggi (3) } \\
\text { - Sangat } \\
\text { Tinggi (4) }\end{array}$ & 26,27 \\
\hline & $\begin{array}{l}\text { Membuat dan } \\
\text { aktif di grup } \\
\text { online untuk } \\
\text { memperluas } \\
\text { jaringan }\end{array}$ & $\begin{array}{l}\text { - Tidak aktif di grup } \\
\text { online } \\
\text { - Kurang aktif di grup } \\
\text { online } \\
\text { - Aktif di grup online } \\
\text { - Sangat aktif di grup } \\
\text { online }\end{array}$ & $\begin{array}{l}\text { - Rendah (1) } \\
\text { - Sedang (2) } \\
\text { - Tinggi (3) } \\
\text { - Sangat } \\
\text { Tinggi (4) }\end{array}$ & 28 \\
\hline & $\begin{array}{l}\text { Etika dalam } \\
\text { berinternet }\end{array}$ & $\begin{array}{l}\text { - Tidak memahami etika } \\
\text { dalam berinternet } \\
\text { - Kurang memahami etika } \\
\text { dalam berinternet } \\
\text { - Memahami etika dalam } \\
\text { berinternet } \\
\text { - Sangat memahami etika } \\
\text { dalam berinternet }\end{array}$ & $\begin{array}{l}\text { - Rendah (1) } \\
\text { - Sedang (2) } \\
\text { - Tinggi (3) } \\
\text { - Sangat } \\
\text { Tinggi (4) }\end{array}$ & 29,30 \\
\hline
\end{tabular}




\begin{tabular}{|c|c|c|c|c|}
\hline Dimensi & Indikator & Kriteria & $\begin{array}{c}\text { Kategori } \\
\text { (Skor) }\end{array}$ & Butir \\
\hline & $\begin{array}{l}\text { Hak cipta dan } \\
\text { lisensi }\end{array}$ & $\begin{array}{l}\text { - Tidak memahami hak } \\
\text { cipta dan lisensi suatu } \\
\text { karya } \\
\text { - Kurang memahami hak } \\
\text { cipta dan lisensi suatu } \\
\text { karya } \\
\text { - Memahami hak cipta } \\
\text { dan lisensi suatu karya } \\
\text { - Sangat memahami hak } \\
\text { cipta dan lisensi suatu } \\
\text { karya }\end{array}$ & $\begin{array}{l}\text { - Rendah (1) } \\
\text { - Sedang (2) } \\
\text { - Tinggi (3) } \\
\text { - Sangat } \\
\text { Tinggi (4) }\end{array}$ & 31,32 \\
\hline
\end{tabular}

Sumber: The Digital Competence Framework for Citizens 2017

Pengukuran variabel perilaku pencarian informasi berbasis digital (Y) diukur menggunakan beberapa indikator yang diturunkan dari dimensi variabel. Dimensi variabel perilaku pencarian informasi terdiri dari dimensi yang dimulai dari tahapan awal (starting), perangkaian (chaining), penelusuran (browsing), diferensiasi (differentiating), pemantauan (monitoring), pengolahan (extracting), verifikasi (verifying), dan akhir (ending). Pengukuran variabel perilaku pencarian informasi (Y) dapat dijelaskan pada Tabel 2.

Tabel 2. Pengukuran Variabel Perilaku Pencarian Informasi

\begin{tabular}{|c|c|c|c|c|}
\hline Dimensi & Indikator & Kriteria & $\begin{array}{l}\text { Kategori } \\
\text { (Skor) }\end{array}$ & Butir \\
\hline \multirow[t]{2}{*}{ 1. Awal (Starting) } & $\begin{array}{l}\text { Penentuan topik } \\
\text { sebelum } \\
\text { melakukan } \\
\text { kegiatan } \\
\text { pencarian } \\
\text { informasi }\end{array}$ & $\begin{array}{l}\text { - Tidak mempersiapkan } \\
\text { penentuan topik } \\
\text { - Kurang mempersiapkan } \\
\text { penentuan topik } \\
\text { - Mempersiapkan } \\
\text { penentuan topik } \\
\text { - Sangat mempersiapkan } \\
\text { penentuan topik }\end{array}$ & $\begin{array}{l}\text { - Rendah (1) } \\
\text { - Sedang (2) } \\
\text { - Tinggi (3) } \\
\text { - Sangat Tinggi } \\
\quad \text { (4) }\end{array}$ & $\begin{array}{l}38 \\
39 \\
40 \\
41\end{array}$ \\
\hline & $\begin{array}{l}\text { Bertanya kepada } \\
\text { orang lain atau } \\
\text { ahli }\end{array}$ & $\begin{array}{l}\text { - Tidak pernah bertanya } \\
\text { kepada orang lain atau } \\
\text { ahli } \\
\text { - Jarang bertanya kepada } \\
\text { orang lain atau ahli } \\
\text { - Sering bertanya kepada } \\
\text { orang lain atau ahli } \\
\text { - Selalu bertanya kepada } \\
\text { orang lain atau ahli }\end{array}$ & $\begin{array}{l}\text { - Rendah (1) } \\
\text { - Sedang (2) } \\
\text { - Tinggi (3) } \\
\text { - Sangat Tinggi } \\
\quad \text { (4) }\end{array}$ & \\
\hline $\begin{array}{l}\text { 2. Perangkaian } \\
\text { (Chaining) }\end{array}$ & $\begin{array}{l}\text { Kemampuan } \\
\text { menulis catatan- } \\
\text { catatan kecil } \\
\text { atau kata kunci } \\
\text { yang dibutuhkan }\end{array}$ & $\begin{array}{l}\text { - Tidak pernah menulis } \\
\text { catatan-catatan kecil atau } \\
\text { kata kunci } \\
\text { - Jarang menulis catatan- } \\
\text { catatan kecil atau kata } \\
\text { kunci } \\
\text { - Sering menulis catatan- } \\
\text { catatan kecil atau kata } \\
\text { kunci } \\
\text { - Selalu menulis catatan- } \\
\text { catatan kecil atau kata } \\
\text { kunci }\end{array}$ & $\begin{array}{l}\text { - Rendah (1) } \\
\text { - Sedang (2) } \\
\text { - Tinggi (3) } \\
\text { - Sangat Tinggi } \\
\quad \text { (4) }\end{array}$ & 42 \\
\hline
\end{tabular}




\begin{tabular}{|c|c|c|c|c|}
\hline Dimensi & Indikator & Kriteria & $\begin{array}{c}\text { Kategori } \\
\text { (Skor) }\end{array}$ & Butir \\
\hline $\begin{array}{l}\text { 3. Penelusuran } \\
\text { (Browsing) }\end{array}$ & $\begin{array}{l}\text { Kemampuan } \\
\text { menelusuri } \\
\text { informasi pada } \\
\text { search engine }\end{array}$ & $\begin{array}{l}\text { - Sangat kesulitan dalam } \\
\text { melakukan penelusuran } \\
\text { informasi pada search } \\
\text { engine } \\
\text { - Agak kesulitan dalam } \\
\text { melakukan penelusuran } \\
\text { informasi pada search } \\
\text { engine } \\
\text { - Kesulitan dalam } \\
\text { melakukan penelusuran } \\
\text { informasi pada search } \\
\text { engine } \\
\text { - Tidak kesulitan dalam } \\
\text { melakukan penelusuran } \\
\text { informasi pada search } \\
\text { engine }\end{array}$ & $\begin{array}{l}\text { - Rendah (1) } \\
\text { - Sedang (2) } \\
\text { - Tinggi (3) } \\
\text { - Sangat Tinggi } \\
\text { (4) }\end{array}$ & $\begin{array}{l}43 \\
44 \\
45\end{array}$ \\
\hline \multirow[t]{2}{*}{$\begin{array}{l}\text { 4. Diferensiasi } \\
\text { (Differentiating) }\end{array}$} & $\begin{array}{l}\text { Menyeleksi } \\
\text { informasi yang } \\
\text { dibutuhkan }\end{array}$ & $\begin{array}{l}\text { - } \text { Tidak memperhatikan } \\
\text { penyeleksian informasi } \\
\text { - Kurang memperhatikan } \\
\text { penyeleksian informasi } \\
\text { Memperhatikan } \\
\text { penyeleksian informasi } \\
\text { - Sangat memperhatikan } \\
\text { penyeleksian informasi }\end{array}$ & $\begin{array}{l}\text { - Rendah (1) } \\
\text { - Sedang (2) } \\
\text { - Tinggi (3) } \\
\text { Sangat Tinggi } \\
\text { (4) }\end{array}$ & $\begin{array}{l}46 \\
47\end{array}$ \\
\hline & $\begin{array}{l}\text { Membandingkan } \\
\text { informasi yang } \\
\text { didapatkan } \\
\text { melalui search } \\
\text { engine dengan } \\
\text { informasi yang } \\
\text { tersedia di } \\
\text { perpustakaan }\end{array}$ & $\begin{array}{l}\text { - Tidak pernah } \\
\text { membandingkan } \\
\text { informasi } \\
\text { - Jarang membandingkan } \\
\text { informasi } \\
\text { - Sering membandingkan } \\
\text { informasi } \\
\text { - Selalu membandingkan } \\
\text { informasi }\end{array}$ & $\begin{array}{l}\text { - Rendah (1) } \\
\text { - Sedang (2) } \\
\text { - Tinggi (3) } \\
\text { - Sangat Tinggi } \\
\quad \text { (4) }\end{array}$ & \\
\hline $\begin{array}{l}\text { 5. Pemantauan } \\
\text { (Monitoring) }\end{array}$ & $\begin{array}{l}\text { Pemantauan } \\
\text { informasi } \\
\text { terbaru (up to } \\
\text { date) }\end{array}$ & $\begin{array}{l}\text { - Tidak pernah melakukan } \\
\text { pemantauan informasi } \\
\text { terbaru } \\
\text { - Jarang melakukan } \\
\text { pemantauan informasi } \\
\text { terbaru } \\
\text { - Sering melakukan } \\
\text { pemantauan informasi } \\
\text { terbaru } \\
\text { - Selalu melakukan } \\
\text { pemantauan informasi } \\
\text { terbaru }\end{array}$ & $\begin{array}{l}\text { - Rendah (1) } \\
\text { - Sedang (2) } \\
\text { - Tinggi (3) } \\
\text { - Sangat Tinggi } \\
\quad(4)\end{array}$ & $\begin{array}{c}48 \\
49\end{array}$ \\
\hline $\begin{array}{l}\text { 6. Pengolahan } \\
\text { (Extracting) }\end{array}$ & $\begin{array}{l}\text { Mengolah } \\
\text { informasi yang } \\
\text { diperoleh dari } \\
\text { berbagai sumber } \\
\text { di search engine }\end{array}$ & $\begin{array}{l}\text { - Sangat kesulitan dalam } \\
\text { mengolah informasi yang } \\
\text { diperoleh } \\
\text { - Kesulitan dalam } \\
\text { mengolah informasi yang } \\
\text { diperoleh }\end{array}$ & $\begin{array}{l}\text { - Rendah (1) } \\
\text { - Sedang (2) } \\
\text { - Tinggi (3) } \\
\text { - Sangat Tinggi } \\
\quad \text { (4) }\end{array}$ & $\begin{array}{l}50 \\
51 \\
52\end{array}$ \\
\hline
\end{tabular}




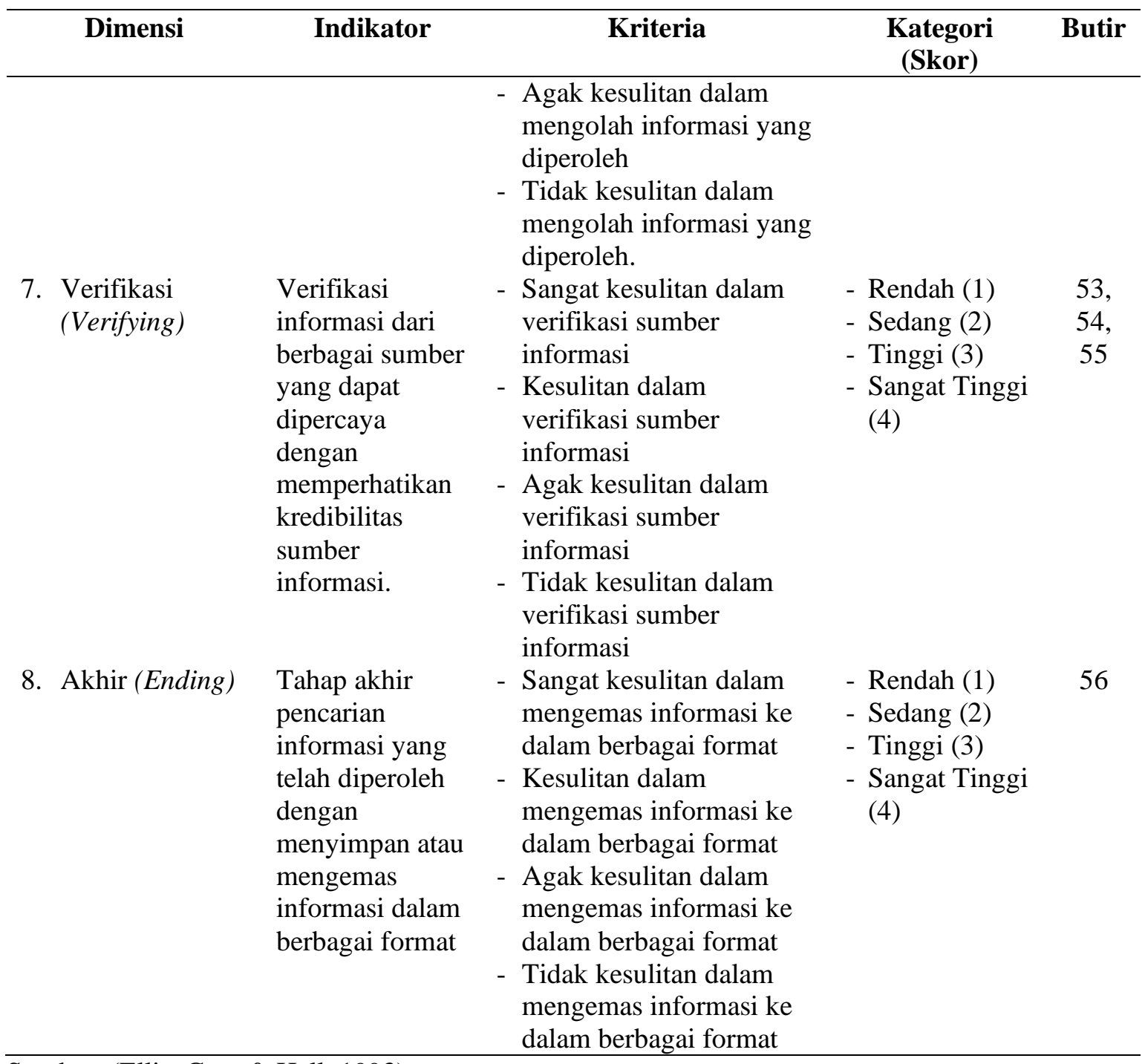

Sumber: (Ellis, Cox, \& Hall, 1993)

Analisis verifikatif digunakan untuk menguji keabsahan dan keandalan suatu instrumen penelitian. Analisis tersebut antara lain adalah uji validitas dan reliabilitas. Uji validitas dan reliabilitas instrumen dilakukan pada 50 responden. Berikut adalah hasil uji validitas dan reliabilitas instrumen penelitian yang terdiri dari variabel literasi digital (X1) dan perilaku pencarian informasi berbasis digital (Y) pada Tabel 1 dan Tabel 2.

Tabel 1. Hasil Uji Validitas Instrumen

\begin{tabular}{ccccccccc}
\hline Variabel & Item & $\mathbf{r}_{\text {hitung }}$ & $\mathbf{r}_{\text {tabel }}$ & Ket. & Item & $\mathbf{r}_{\text {hitung }}$ & $\mathbf{r}_{\text {tabel }}$ & Ket. \\
\hline 12 & 0,589 & 0,2732 & Valid & 22 & 0,657 & 0,2732 & Valid \\
& 13 & 0,540 & 0,2732 & Valid & 23 & 0,763 & 0,2732 & Valid \\
Kemampuan Literasi & 14 & 0,568 & 0,2732 & Valid & 24 & 0,552 & 0,2732 & Valid \\
Digital $\left(\mathrm{X}_{1}\right)$ & 15 & 0,616 & 0,2732 & Valid & 25 & 0,574 & 0,2732 & Valid \\
& 16 & 0,552 & 0,2732 & Valid & 26 & 0,753 & 0,2732 & Valid \\
& 17 & 0,677 & 0,2732 & Valid & 27 & 0,621 & 0,2732 & Valid \\
& 18 & 0,661 & 0,2732 & Valid & 28 & 0,514 & 0,2732 & Valid \\
& 19 & 0,568 & 0,2732 & Valid & 29 & 0,627 & 0,2732 & Valid \\
& 20 & 0,580 & 0,2732 & Valid & 30 & 0,629 & 0,2732 & Valid \\
& 21 & 0,797 & 0,2732 & Valid & 31 & 0,639 & 0,2732 & Valid \\
\hline 12 & 0,589 & 0,2732 & Valid & 22 & 0,657 & 0,2732 & Valid \\
& 13 & 0,540 & 0,2732 & Valid & 23 & 0,763 & 0,2732 & Valid
\end{tabular}




\begin{tabular}{ccccccccc}
\hline Variabel & Item & $\mathbf{r}_{\text {hitung }}$ & $\mathbf{r}_{\text {tabel }}$ & Ket. & Item & $\mathbf{r}_{\text {hitung }}$ & $\mathbf{r}_{\text {tabel }}$ & Ket. \\
\hline Perilaku Pencarian & 14 & 0,568 & 0,2732 & Valid & 24 & 0,552 & 0,2732 & Valid \\
Informasi (Y) & 15 & 0,616 & 0,2732 & Valid & 25 & 0,574 & 0,2732 & Valid \\
& 16 & 0,552 & 0,2732 & Valid & 26 & 0,753 & 0,2732 & Valid \\
& 17 & 0,677 & 0,2732 & Valid & 27 & 0,621 & 0,2732 & Valid \\
& 18 & 0,661 & 0,2732 & Valid & 28 & 0,514 & 0,2732 & Valid \\
& 19 & 0,568 & 0,2732 & Valid & 29 & 0,627 & 0,2732 & Valid \\
\hline
\end{tabular}

Sumber: Analisis Data Primer 2020

Tabel 1 merupakan hasil uji validitas instrumen variabel literasi digital $(\mathrm{X})$ dan perilaku pencarian informasi (Y). Item instrumen dikatakan valid apabila $r$ hitung $>r$ tabel (Arikunto, 2002). Uji validitas pada penelitian ini ditujukan untuk 50 responden dengan taraf signifikansi 5\% untuk uji dua arah (two-tailed), maka didapatkan r-tabel 0,2732. Hasil perhitungan uji validitas instrumen literasi digital (X) dan perilaku pencarian informasi (Y) dengan menggunakan bantuan aplikasi IBM SPSS menunjukkan bahwa seluruh item pada instrumen literasi digital dinyatakan valid karena seluruh nilai $r$ hitung $>r$ tabel

Tabel 2. Hasil Uji Reliabilitas Instrumen

\begin{tabular}{lcc}
\multicolumn{1}{c}{ Variabel } & Cronbach's Alpha & Keterangan \\
\hline Literasi Digital (X) & 0,916 & Sangat Reliabel \\
Perilaku Pencarian Informasi (Y) & 0,937 & Sangat Reliabel \\
\hline
\end{tabular}

Sumber: Analisis Data Primer 2020

Tabel 2 merupakan hasil uji reliabilitas instrumen variabel literasi digital (X) dan perilaku pencarian informasi (Y). Uji reliabilitas mengacu pada akurasi, ketepatan, dan konsistensi kuesioner dalam mengukur variabel (Latan \& Temalagi, 2013). Uji reliabilitas pada penelitian ini menggunakan koefisien Cronbach's Alpha pada alat ukur tersebut dengan menggunakan program IBM SPSS. Uji reliabilitas pada penelitian ini ditujukan pada 50 responden. Hasil uji reliabilitas instrumen literasi digital dan perilaku pencarian informasi menunjukkan koefisien Cronbach's Alpha sebesar 0,916 dan 0,937. Berdasarkan angka koefisien tersebut pada uji reliabilitas menunjukkan bahwa instrumen sangat reliabel sesuai dengan kaidah Reliabilitas Guilford.

Uji asumsi klasik bertujuan untuk mengetahui apakah dalam suatu persamaan regresi terdapat gejala atau masalah statistik. Model regresi yang baik harus memenuhi asumsi klasik. Uji asumsi klasik yang digunakan pada penelitian ini adalah uji normalitas, uji multikolinearitas, dan uji heteroskedastisitas. Hasil uji asumsi klasik dapat dilihat pada tabel berikut dibawah ini.

Tabel 3. Hasil Uji Normalitas

\begin{tabular}{ccc}
\hline Uji Kolmogorov-Smirnov & Unstandardized Residual & Keterangan \\
\hline Nilai Kolmogorov-Smirnov & 0,043 & \multirow{2}{*}{ Data terdistribusi normal } \\
Sig. & 0,200 & \\
\hline
\end{tabular}

Sumber: Analisis Data Primer 2020

Tabel 3 merupakan hasil uji normalitas Kolmogorov-Smirnov menggunakan alat bantu IBM SPSS 26. Uji normalitas bertujuan untuk melihat apakah model regresi mempunyai distribusi data yang normal atau tidak (Ghozali, 2001). Data dikatakan terdistribusi normal apabila nilai signifikan lebih besar dari taraf signifikansi yaitu 0,05 (Siregar, 2014). Hasil uji normalitas Kolmogorov-Smirnov signifikan pada 0,200 dimana nilai tersebut lebih besar dari taraf signifikansi 0,05 . Hasil tersebut menunjukkan model persamaan regresi telah memenuhi asumsi normalitas atau dapat dikatakan data terdistribusi secara normal.

Tabel 4. Hasil Uji Multikolinearitas

\begin{tabular}{ccc}
\hline Variabel & \multicolumn{2}{c}{ Collinearity Statistics } \\
\cline { 2 - 3 } & Tolerance & Variance Inflation Factors (VIF) \\
\hline Kemampuan literasi digital $\left(\mathrm{X}_{1}\right)$ & 0,916 & 1,092 \\
Usia $\left(\mathrm{X}_{2}\right)$ & 0,444 & 2,254 \\
Tingkat pendidikan formal $\left(\mathrm{X}_{3}\right)$ & 0,885 & 1,139 \\
Pengalaman kerja $\left(\mathrm{X}_{4}\right)$ & 0,473 & 2,114 \\
Tingkat penggunaan media $\left(\mathrm{X}_{5}\right)$ & 0,880 & 1,137 \\
\hline
\end{tabular}

Sumber: Analisis Data Primer 2020 
Tabel 4 merupakan hasil uji multikolinearitas menggunakan alat bantu IBM SPSS 26. Uji multikolinearitas bertujuan untuk melihat apakah variabel independen memiliki hubungan dengan variabel independen lainnya (Ghozali, 2001). Nilai VIF $\leq 10$ dan nilai tolerance $>0,1$ menunjukkan bahwa persamaan model regresi tidak memiliki gejala multikolinearitas antar variabel independen (Gani \& Amalia, 2015). Nilai tolerance dan Variance Inflation Factors (VIF) pada Tabel 4 menunjukkan bahwa model persamaan regresi telah memenuhi asumsi non multikolinearitas atau dapat dikatakan antar variabel independen tidak terjadi persoalan multikolinearitas.

Tabel 5. Hasil Uji Heteroskedastisitas

\begin{tabular}{|c|c|}
\hline Variabel & Sig. \\
\hline Kemampuan literasi digital $\left(\mathrm{X}_{1}\right)$ & 0,133 \\
\hline Usia $\left(\mathrm{X}_{2}\right)$ & 0,655 \\
\hline Tingkat pendidikan formal $\left(\mathrm{X}_{3}\right)$ & 0,773 \\
\hline Pengalaman kerja $\left(\mathrm{X}_{4}\right)$ & 0,800 \\
\hline Tingkat penggunaan media $\left(\mathrm{X}_{5}\right)$ & 0,400 \\
\hline
\end{tabular}

Sumber: Analisis Data Primer 2020

Tabel 5 merupakan hasil uji heteroskedastisitas dengan uji Glejser menggunakan alat bantu IBM SPSS 26. Uji heteroskedastisitas bertujuan untuk menguji apakah dalam persamaan model regresi terjadi ketidaksamaan varian dari nilai sisa satu pengamatan (observer) ke pengamatan lainnya. Model regresi linier yang baik adalah regresi yang berada dalam posisi homoskedastisitas (Utomo, 2009). Nilai signifikan lebih besar dari taraf signifikansi yaitu 0,05 menunjukkan bahwa model regresi tersebut tidak memiliki gejala heteroskedastisitas atau dapat dikatakan model regresi homoskedastisitas (Gani \& Amalia, 2015). Hasil uji heteroskedastisitas menggunakan uji Glejser menunjukkan bahwa persamaan model persamaan regresi pada penelitian ini tidak terjadi masalah heteroskedastisitas.

Analisis data yang digunakan dalam penelitian ini adalah analisis regresi linier berganda (multiple regression analysis). Analisis regresi linier berganda bertujuan untuk mengetahui seberapa besar pengaruh variabel bebas terhadap variabel terikat. Tahapan analisis ini terdiri dari persamaan regresi, uji simultan (uji F), uji parsial (uji t), dan koefisien determinasi $\left(\mathrm{R}^{2}\right)$.

\section{HASIL DAN PEMBAHASAN}

\section{Perilaku Pencarian Informasi}

Perilaku pencarian informasi berbasis digital merupakan perilaku di tingkat mikro, berupa perilaku mencari yang ditunjukkan seseorang ketika berinteraksi dengan sistem informasi. Variabel perilaku pencarian informasi pada penelitian ini merupakan skor total dari tahapan perilaku pencarian informasi yang dikemukakan oleh Ellis. Tahapan tersebut antara lain adalah tahapan awal (starting), perangkaian (chaining), penelusuran (browsing), diferensiasi (differentiating), pemantauan (monitoring), pengolahan (extracting), verifikasi (verifying), dan akhir (ending) (Ellis et al., 1993). Distribusi responden berdasarkan skor perilaku pencarian informasi dapat dilihat pada Tabel 6.

Tabel 6. Distribusi Responden Berdasarkan Perilaku Pencarian Informasi

\begin{tabular}{cccc}
\hline Kategori & Skor & Frekuensi (orang) & Persentase (\%) \\
\hline Rendah & $18,00-32,50$ & 0 & $0,0 \%$ \\
Sedang & $32,51-47,00$ & 8 & $5,2 \%$ \\
Tinggi & $47,01-61,50$ & 99 & $63,9 \%$ \\
Sangat Tinggi & $61,51-76,00$ & 48 & $31 \%$ \\
\hline
\end{tabular}

Sumber: Analisis Data Primer 2020

Tabel 6 menunjukkan bahwa rata-rata responden penyuluh pertanian dalam penelitian ini sebagian besar memiliki perilaku pencarian informasi berbasis digital yang tinggi yaitu penyuluh telah melaksanakan semua tahapan yang ada dalam perilaku pencarian informasi berbasis digital. Penyuluh tidak memiliki masalah dalam melakukan pencarian informasi yaitu dimulai dari menganalisa topik masalah yang ditemui sebelum melakukan pencarian informasi (starting), menentukan sumber rujukan (chaining), melakukan pencarian informasi di internet, blog, maupun 
sosial media (browsing), melakukan pemantauan terhadap perkembangan informasi (monitoring), memilih dan merangkum melalui diskusi (extracting), dan penyelesaian (ending) (Aprilla, 2017).

Kondisi tersebut mengindikasikan bahwa penyuluh pertanian sebagai sumber informasi petani sudah dapat memanfaatkan internet dan sosial media dengan maksimal untuk dapat mencari informasi yang dibutuhkan oleh petani. Perilaku pencarian informasi dalam penelitian ini adalah kegiatan pencarian informasi yang dilakukan oleh penyuluh pertanian mulai dari sikap/cara penyuluh mengklik sebuah link dalam pencarian informasi untuk mendapatkan informasi yang relevan dengan tujuan agar dapat memenuhi kebutuhan informasi demi menunjang kegiatan penyuluhan pertanian. Pemenuhan kebutuhan informasi tersebut dilakukan penyuluh dengan menggunakan perangkat media digital dan teknologi informasi.

\section{Faktor-Faktor Pembentuk Perilaku Proses Pencarian Informasi Berbasis Digital}

\section{Kemampuan Literasi Digital $\left(X_{1}\right)$}

Kemampuan literasi digital merupakan kemampuan seseorang dalam memahami dan menggunakan teknologi digital sebagai bentuk komunikasi secara beretika dan dapat dipertanggungjawabkan. Variabel kemampuan literasi digital pada penelitian ini merupakan skor total dari 2 dimensi yang mengacu pada framework DIGCOMP 2.1. Dimensi tersebut antara lain adalah informasi dan literasi data serta komunikasi dan kolaborasi. Distribusi responden berdasarkan skor variabel kemampuan literasi digital dapat dilihat pada Tabel 7.

Tabel 7. Distribusi Responden Berdasarkan Skor Kemampuan Literasi Digital

\begin{tabular}{cccc}
\hline Kategori & Skor & Frekuensi (orang) & Persentase (\%) \\
\hline Rendah & $21,00-36,75$ & 0 & $0 \%$ \\
Sedang & $36,76-52,50$ & 7 & $4,5 \%$ \\
Tinggi & $52,51-68,25$ & 100 & $64,5 \%$ \\
Sangat Tinggi & $68,26-84,00$ & 48 & $31 \%$ \\
\hline
\end{tabular}

Sumber: Analisis Data Primer 2020

Tabel 7 menunjukkan bahwa rata-rata responden penyuluh pertanian dalam penelitian ini sebagian besar memiliki kemampuan literasi digital yang tinggi atau dapat dikatakan sudah berada pada tingkat yang baik. Kondisi tersebut mengindikasikan bahwa responden atau penyuluh pertanian dalam penelitian ini sudah memiliki kesadaran yang tinggi akan pentingnya literasi digital dalam pekerjaan yang dilakukan. Penyuluh pertanian perlu memiliki keterampilan literasi digital dalam menjalankan tugasnya sebagai penyuluh. Literasi digital merupakan keterampilan dasar abad 21 yang diakui dan diterima secara luas untuk semua jenis pekerjaan dari level bawah hingga eksekutif (Eisenberg, 2008). Literasi digital merupakan kunci keberhasilan penyuluh dalam menyampaikan informasi yang telah tersaring kepada petani. Literasi digital yang dimiliki oleh penyuluh sebagai sumber informasi akan memengaruhi kepercayaan sasaran penyuluh yaitu petani. Kepercayaan petani kepada penyuluh sebagai sumber informasi akan meningkat jika penyuluh dapat menggunakan perangkat digital dan teknologi informasi dengan baik (Singh, 2018).

Usia $\left(X_{2}\right)$

Usia merupakan waktu (tahun) yang terlewat sejak kelahiran. Usia merupakan salah satu karakteristik pribadi dari penyuluh pertanian yang mempengaruhi fungsi biologis dan psikologis individu penyuluh. Responden berdasarkan usia dapat dijelaskan pada Tabel 8.

Tabel 8. Distribusi Responden Berdasarkan Usia

\begin{tabular}{lcc}
\hline & Usia & Jumlah (orang) \\
\hline $30-39$ Tahun & 89 \\
$40-49$ Tahun & 30 \\
$50-59$ Tahun & 35 \\
$\geq 60$ Tahun & 1 \\
\hline
\end{tabular}

Sumber: Analisis Data Primer 2020

Tabel 8 menunjukkan bahwa rata-rata usia penyuluh di Jawa Tengah yang aktif menggunakan perangkat digital dalam melakukan kegiatan pencarian informasi masih berada pada usia produktif (15-64 tahun). Kondisi tersebut sesuai dengan peraturan penyuluh pertanian PNS yaitu batas usia 
pensiun sampai dengan 60 tahun. Usia akan berpengaruh pada kemampuan penyuluh pertanian dalam memahami, menggunakan, dan mengadopsi suatu teknologi khususnya digital. Penyuluh usia muda akan lebih cakap menggunakan teknologi internet dibandingkan penyuluh usia tua (Wijaya et al., 2019). Penyuluh senior cenderung sulit untuk mempelajari teknologi digital dan membutuhkan waktu yang lama untuk belajar dibandingkan penyuluh usia muda.

\section{Tingkat Pendidikan Formal $\left(X_{3}\right)$}

Tingkat pendidikan formal merupakan jenjang pendidikan formal terakhir seorang penyuluh pertanian yang telah diselesaikan dengan memperoleh ijazah. Responden berdasarkan tingkat pendidikan formal dapat dijelaskan pada Tabel 9.

Tabel 9. Distribusi Responden Berdasarkan Tingkat Pendidikan Formal

\begin{tabular}{lc}
\multicolumn{1}{c}{ Tingkat Pendidikan Formal } & Jumlah (orang) \\
\hline SMA/SMK & 12 \\
D3 & 23 \\
S1 & 109 \\
Pascasarjana & 11 \\
\hline
\end{tabular}

Sumber: Analisis Data Primer 2020

Tabel 9 menunjukkan bahwa responden penyuluh pertanian dalam penelitian ini sebagian besar telah menyelesaikan program pendidikan sarjana. Hal tersebut mengindikasikan bahwa sebagian besar penyuluh pada penelitian ini sudah menyelesaikan pendidikan di perguruan tinggi termasuk diploma, sarjana, maupun pascasarjana. Syarat untuk menjadi tenaga penyuluh saat ini adalah minimal berpendidikan ahli madya oleh karena itu hal ini bisa dikatakan wajar (Wijaya et al., 2019). Tingkat pendidikan seseorang akan berpengaruh terhadap akses inovasi teknologi (Okwu \& Umoru, 2009). Pemerintah perlu mendorong penyuluh pertanian untuk melanjutkan pendidikan terutama bagi penyuluh pertanian usia muda. Pendidikan digunakan sebagai landasan untuk mengembangkan kemampuan sumber daya manusia. Pendidikan penyuluh pertanian akan sangat mempengaruhi kemampuan mengembangkan ide, menggerakkan dan memeliharakan partisipasi masyarakat (Mardikanto, 2010). Jenjang pendidikan berperan dalam meningkatkan peran dan status sehingga banyak saat ini penyuluh pertanian melanjutkan pendidikan ke jenjang sarjana maupun pascasarjana (Suhanda et al., 2008)

\section{Pengalaman Kerja $\left(\mathrm{X}_{4}\right)$}

Pengalaman kerja sebagai penyuluh menentukan pengalaman kerja penyuluh dalam melaksanakan tugas pokok dan fungsinya. Pengalaman kerja diukur berdasarkan berapa lama waktu (tahun) yang dihabiskan tenaga kerja pada suatu bidang pekerjaan tertentu (Sulaeman, 2014). Responden berdasarkan lama bekerja sebagai penyuluh dapat dijelaskan pada Tabel 10.

Tabel 10. Distribusi Responden Berdasarkan Pengalaman Kerja

\begin{tabular}{lc}
\multicolumn{1}{c}{ Pengalaman Kerja (Tahun) } & Jumlah (orang) \\
\hline$\leq 2$ Tahun & 0 \\
$2-10$ Tahun & 34 \\
$10-20$ Tahun & 86 \\
$\geq 20$ Tahun & 35 \\
\hline
\end{tabular}

Sumber: Analisis Data Primer 2020

Tabel 10 menunjukkan bahwa responden penyuluh pertanian dalam penelitian ini sebagian besar telah bekerja sebagai penyuluh selama $10-20$ Tahun. Hal tersebut mengindikasikan bahwa sebagian besar penyuluh pada penelitian ini sudah berpengalaman lama menjadi penyuluh yang ditunjukkan dengan lebih dari 10 tahun bekerja sebagai penyuluh. Penyuluh yang berpengalaman lama bekerja sebagai penyuluh akan memiliki kemampuan yang lebih baik dibandingkan dengan mereka yang belum lama menjadi penyuluh (Suhardiyono, 1992). Lama seseorang bekerja pada suatu bidang pekerjaan membuat seseorang menjadi lebih tahu dan terampil dalam mengerjakan sesuatu (Budhyani, 2008). 


\section{Tingkat Penggunaan Media $\left(X_{5}\right)$}

Tingkat penggunaan media merupakan tingkat ketersediaan penyuluh dalam mengakses internet untuk mencari informasi. Tingkat penggunaan media oleh penyuluh pada penelitian ini diukur berdasarkan ketersediaan sarana dan biaya operasional akses internet oleh penyuluh pertanian. Variabel tingkat penggunaan media oleh penyuluh pada penelitian ini merupakan skor total yang meliputi pernyataan ketersediaan sarana dan akses internet serta biaya operasional akses internet. Kategori responden berdasarkan skor tingkat penggunaan media dapat dilihat pada Tabel 11.

Tabel 11. Distribusi Responden Berdasarkan Tingkat Penggunaan Media

\begin{tabular}{cccc}
\hline Kategori & Skor & Frekuensi (orang) & Persentase (\%) \\
\hline Rendah & $2,0-3,5$ & 5 & $3,2 \%$ \\
Sedang & $3,6-5,0$ & 51 & $32,9 \%$ \\
Tinggi & $5,1-6,5$ & 54 & $34,8 \%$ \\
Sangat Tinggi & $6,6-8,0$ & 45 & $29,0 \%$ \\
\hline
\end{tabular}

Sumber: Analisis Data Primer 2020

Tabel 5.10 menunjukkan bahwa rata-rata responden penyuluh pertanian dalam penelitian ini sebagian besar memiliki tingkat penggunaan media yang tinggi.. Hal ini mengindikasikan bahwa tingkat penggunaan media oleh penyuluh pertanian pada penelitian ini berada pada kategori tinggi atau dapat dikatakan sudah baik. Ketersediaan sarana dan akses internet oleh penyuluh pada penelitian ini dilihat berdasarkan fasilitas, sarana, dan akses internet yang memadai. Penyuluh pertanian Jawa Tengah pada penelitian ini telah mendapatkan fasilitas, sarana, dan akses internet yang memadai. Hal tersebut menunjukkan bahwa pemerintah telah berupaya dengan baik untuk memfasilitasi penyuluh pertanian dalam hal fasilitas, sarana, dan akses internet untuk membantu kinerja penyuluh pertanian. Ketersediaan sarana dan fasilitas maupun akses internet yang memadai akan membantu meningkatkan kinerja penyuluh (Wijaya et al., 2019).

Biaya operasional akses internet oleh penyuluh pada penelitian ini dilihat berdasarkan nominal uang yang dikeluarkan penyuluh dalam satu bulan untuk dapat mengakses internet dengan baik. Penyuluh pertanian Jawa Tengah pada penelitian ini rata-rata mengeluarkan biaya operasional akses internet yang tinggi. Penyuluh pertanian membutuhkan waktu yang banyak di lapangan bersama petani sehingga kebutuhan mencari informasi di internet juga semakin banyak. Fasilitas dan sarana internet yang didapatkan penyuluh pertanian saat ini hanya difasilitasi saat berada di kantor sehingga penyuluh masih menggunakan biaya sendiri untuk mendapatkan akses internet ketika berada di lapangan.

\section{Pengaruh Faktor-Faktor Pembentuk Perilaku Pencarian Informasi Terhadap Perilaku Pencarian Informasi Penyuluh Pertanian Jawa Tengah}

\section{Persamaan Regresi}

Analisis regresi dilakukan untuk mengetahui pengaruh antara dua atau lebih variabel independen dengan variabel dependen. Analisis regresi linier berganda dilakukan menggunakan alat bantu IBM SPSS 26 . Hasil model persamaan regresi linier berganda adalah sebagai berikut: $Y=6,045+0,788 X_{1}-0,052 X_{2}+1,116 X_{3}+1,053 X_{4}+0,259 X_{5}$

\section{Uji Simultan (Uji F)}

Uji simultan atau uji $\mathrm{F}$ bertujuan untuk mengetahui pengaruh variabel independen secara bersama-sama terhadap variabel dependen. Hasil uji simultan dilakukan dengan membandingkan pvalue dengan tingkat signifikansi $(\alpha)$ yaitu 0,05. Hasil uji simultan dapat dilihat pada Tabel 12.

Tabel 12. Hasil Uji Simultan (Uji F)

\begin{tabular}{cccccc}
\hline Model & $\begin{array}{c}\text { Sum of } \\
\text { Squares }\end{array}$ & $\boldsymbol{d f}$ & Mean Square & F & Sig. \\
\hline Regression & $6.917,960$ & 5 & $1.383,592$ & 69,352 & 0,000 \\
Residual & $2.972,595$ & 149 & 19,950 & & \\
Total & $9.890,555$ & 154 & & & \\
\hline
\end{tabular}

Sumber: Analisis Data Primer 2020 
Tabel 5.11 menunjukkan bahwa nilai p-value pada kolom Sig. lebih kecil dari taraf signifikansi $(\alpha)$ yaitu 0,05 sehingga dapat disimpulkan bahwa variabel independen yaitu kemampuan literasi digital $\left(\mathrm{X}_{1}\right)$, usia $\left(\mathrm{X}_{2}\right)$, tingkat pendidikan formal $\left(\mathrm{X}_{3}\right)$, pengalaman kerja $\left(\mathrm{X}_{4}\right)$, dan tingkat penggunaan media $\left(\mathrm{X}_{5}\right)$ secara simultan atau bersama-sama memiliki pengaruh terhadap perilaku pencarian informasi berbasis digital $(\mathrm{Y})$.

\section{Uji Parsial (Uji t)}

Uji t bertujuan untuk mengetahui apakah terdapat pengaruh masing-masing variabel independen secara individual terhadap variabel dependen. Hasil uji parsial (uji t) dilakukan dengan membandingkan $p$-value pada kolom Sig. dengan tingkat signifikansi $(\alpha)$ yaitu 0,05 . Hasil uji parsial dapat dilihat pada Tabel 13.

Tabel 13. Hasil Uji Parsial (Uji t)

\begin{tabular}{|c|c|c|}
\hline Model & $t$ & Sig. \\
\hline (Constant) & 1,170 & 0,244 \\
\hline Kemampuan literasi digital $\left(\mathrm{X}_{1}\right)$ & 17,721 & 0,000 \\
\hline Usia $\left(X_{2}\right)$ & $-0,082$ & 0,935 \\
\hline Tingkat pendidikan formal $\left(\mathrm{X}_{3}\right)$ & 2,016 & 0,046 \\
\hline Pengalaman kerja $\left(\mathrm{X}_{4}\right)$ & 1,346 & 0,047 \\
\hline Tingkat penggunaan media $\left(\mathrm{X}_{5}\right)$ & 0,830 & 0,408 \\
\hline
\end{tabular}

Sumber: Analisis Data Primer

\section{Pengaruh Kemampuan Literasi Digital $\left(X_{1}\right)$ Terhadap Perilaku Pencarian Informasi}

Variabel kemampuan literasi digital secara parsial berpengaruh nyata terhadap perilaku pencarian informasi karena nilai $p$-value pada kolom Sig. lebih kecil dari taraf signifikansi $(\alpha)$ yaitu 0,05 . Literasi digital mempunyai pengaruh yang signifikan terhadap perilaku pencarian informasi (Hafidhah, 2020). Literasi digital sangat berkaitan dengan kemampuan individu untuk dapat mencari informasi di internet. Kompetensi utama literasi digital adalah bagaimana seseorang dapat mencari dan menemukan informasi sesuai dengan kebutuhannya.

\section{Pengaruh Usia $\left(\mathrm{X}_{2}\right)$ Terhadap Perilaku Pencarian Informasi}

Variabel usia secara parsial tidak berpengaruh nyata terhadap perilaku pencarian informasi karena nilai $p$-value pada kolom Sig. lebih besar dari taraf signifikansi $(\alpha)$ yaitu 0,05 . Tinggi atau tidaknya usia penyuluh tidak berpengaruh terhadap perilaku pencarian informasi. Hal ini diduga karena penyuluh pertanian yang sudah tergolong berumur tua akan melakukan pencarian informasi berdasarkan pengalaman dan cenderung tidak begitu mementingkan mencari informasi ide internet. Perilaku pencarian informasi melalui berbagai media komunikasi akan berkurang seiring dengan bertambahnya usia seseorang (Yusup, 2013). Kekuatan media jika dikaitkan dengan usia seseorang akan mengalami penurunan. Semakin tua umur seseorang maka akan semakin lambat berpikir dan menerima informasi sehingga cenderung hanya akan melaksanakan kegiatan tanpa memikirkan rencana pengembangan (Tamba \& Sarma, 2007).

\section{Pengaruh Tingkat Pendidikan Formal $\left(X_{3}\right)$ Terhadap Perilaku Pencarian Informasi}

Variabel tingkat pendidikan formal berpengaruh secara nyata terhadap perilaku pencarian informasi karena nilai $p$-value pada kolom Sig. lebih kecil dari taraf signifikansi $(\alpha)$ yaitu 0,05 . Semakin tinggi tingkat pendidikan seseorang maka akan semakin tinggi pula perilaku komunikasi dalam mencari informasi untuk memenuhi kebutuhannya (Hussein, 2019). Tingkat pendidikan penyuluh pertanian yang tinggi diharapkan dapat meningkatkan pengetahuan dan keterampilan penyuluh dalam melaksanakan tugasnya sebagai penyuluh pertanian. Tingkat pendidikan formal merupakan upaya pengembangan aspek intelektual sumberdaya manusia. Semakin tinggi tingkat pendidikan seseorang maka akan ada kecenderungan semakin tinggi pula pengetahuan dan keterampilan yang dimiliki (Slamet, 1992). Tingkat pendidikan yang memengaruhi perilaku pencarian informasi oleh penyuluh pertanian pernah diteliti sebelumnya oleh (Kuncel et al., 2004), (Springer et al., 2005), (Bahua et al., 2010), dan (Matindas et al., 2013) yang menunjukkan bahwa pendidikan formal dapat memengaruhi perilaku pencarian informasi berbasis digital oleh penyuluh 


\section{Pengaruh Pengalaman Kerja $\left(X_{4}\right)$ Terhadap Perilaku Pencarian Informasi}

Variabel pengalaman kerja berpengaruh secara nyata terhadap perilaku pencarian informasi karena nilai $p$-value pada kolom Sig. lebih kecil dari taraf signifikansi $(\alpha)$ yaitu 0,05 . Penyuluh yang memiliki tingkat pengalaman bekerja yang lebih tinggi menunjukkan perilaku pencarian informasi yang lebih tinggi bila dibandingkan dengan penyuluh yang memiliki pengalaman bekerja lebih rendah (Dinpanah \& Lashgarara, 2011). Semakin lama seorang penyuluh pertanian bekerja maka penyuluh tersebut akan semakin lancar dan terampil dalam melakukan kegiatan pencarian informasi di internet. Semakin lancar dan terampil penyuluh pertanian dalam mencari informasi maka akan semakin berkualitas informasi atau materi pertanian yang dihasilkan oleh penyuluh.

\section{Pengaruh Tingkat Penggunaan Media $\left(X_{5}\right)$ Terhadap Perilaku Pencarian Informasi}

Variabel tingkat penggunaan media secara parsial tidak berpengaruh nyata terhadap perilaku pencarian informasi karena nilai $p$-value pada kolom Sig. lebih besar dari taraf signifikansi $(\alpha)$ yaitu 0,05 . Tinggi atau tidaknya tingkat penggunaan media oleh penyuluh tidak berpengaruh terhadap perilaku pencarian informasi. Hal ini diduga karena tingkat penggunaan media dalam hal ketersediaan fasilitas dan sarana serta biaya operasional akses internet masing-masing wilayah sangat beragam. Fasilitas dan sarana akses internet beberapa wilayah ada yang sudah memadai namun beberapa wilayah lain mungkin belum memadai, adapun sama halnya dengan biaya operasional akses internet oleh penyuluh yang setiap wilayah memiliki biaya operasional yang berbeda tergantung dari akses sinyal wilayah, intensitas kegunaan untuk mencari informasi di internet, dan biaya oleh provider internet yang berbeda di setiap wilayah.

Penggunaan media oleh penyuluh pertanian dalam hal ketersediaan sarana akses internet cukup memadai. Fasilitas seperti komputer, jaringan internet di kantor penyuluh sudah cukup memadai. Fasilitas tersebut sangat membantu kinerja penyuluh. Fasilitas komputer di kantor penyuluh biasanya digunakan untuk mengerjakan laporan atau tugas penyuluh pertanian. Ketersediaan akses internet untuk penyuluh menjadi hal penting untuk membantu kinerja penyuluh (Wijaya et al., 2019).

Penggunaan media oleh penyuluh dalam hal biaya operasional akses internet termasuk tinggi. Penyuluh pertanian saat ini masih menggunakan biaya sendiri untuk mengakses internet ketika berada di lapangan. Fakta membuktikan bahwa penyuluh pertanian membutuhkan waktu yang banyak di lapangan bersama petani sehingga kebutuhan mencari informasi di internet juga semakin banyak. Dana yang digunakan untuk biaya operasional akses internet oleh penyuluh di kantor berasal dari BP3K yang jumlahnya terkadang masih kurang mencukupi (Wijaya et al., 2019).

\section{Koefisien Determinasi}

Koefisien determinasi $\left(\mathrm{R}^{2}\right)$ bertujuan untuk mengukur seberapa jauh kemampuan sebuah model regresi linier menjelaskan variasi variabel dependen. Koefisien determinasi dilakukan dengan melihat persentase (\%) pada Adjusted $R$ Square di tabel model summary analisis regresi linier berganda. Hasil model summary dapat dilihat pada Tabel 14.

Tabel 14. Hasil Model Summary Koefisien Determinasi

\begin{tabular}{cccc}
\hline $\mathbf{R}$ & $\boldsymbol{R}$ Square & Adjusted $\boldsymbol{R}$ Square & Std. Error of the Estimate \\
\hline 0,836 & 0,699 & 0,691 & 4,452 \\
\hline
\end{tabular}

Sumber: Analisis Data Primer 2020

Tabel 14 menunjukkan hasil koefisien determinasi $\left(\mathrm{R}^{2}\right)$ diperoleh nilai Adjusted $R$ Square sebesar 0,691 atau 69,1\%. Hasil tersebut menunjukkan bahwa variasi variabel perilaku pencarian informasi dapat dijelaskan oleh variabel kemampuan literasi digital $\left(\mathrm{X}_{1}\right)$, usia $\left(\mathrm{X}_{2}\right)$, tingkat pendidikan formal $\left(\mathrm{X}_{3}\right)$, lama menjadi penyuluh $\left(\mathrm{X}_{4}\right)$, dan tingkat penggunaan media $\left(\mathrm{X}_{5}\right)$ sebesar $69,1 \%$ sedangkan sisanya 30,9\% dipengaruhi oleh variabel yang belum diteliti.

\section{SIMPULAN DAN SARAN}

Berdasarkan hasil analisis dan pembahasan pada penelitian ini dapat disimpulkan bahwa variabel kemampuan literasi digital, usia, tingkat pendidikan formal, pengalaman kerja, dan tingkat penggunaan media secara simultan atau bersama-sama memiliki pengaruh yang signifikan terhadap perilaku pencarian informasi berbasis digital oleh penyuluh pertanian. Kemampuan literasi digital, 
tingkat pendidikan formal, dan pengalaman kerja secara parsial memiliki pengaruh yang signifikan terhadap perilaku pencarian informasi berbasis digital, sedangkan usia dan tingkat penggunaan media secara parsial tidak memiliki pengaruh yang signifikan terhadap perilaku pencarian informasi berbasis digital oleh penyuluh pertanian.

PERHIPTANI diharapkan dapat menjadi jembatan dalam memfasilitasi penyuluh dalam mendukung peningkatan kompetensi digital oleh penyuluh pertanian yang berkaitan dengan fasilitas maupun akses internet yang digunakan penyuluh pertanian. PERHIPTANI sebagai organisasi profesi penyuluh pertanian Indonesia perlu mempertahankan dan meningkatkan kegiatan pelatihan, kursus, seminar, kerja sama lembaga profesi sebagai bentuk pengembangan kualitas anggota (penyuluh pertanian) khususnya dalam hal kompetensi digital. Perlu diadakannya penelitian lebih lanjut dan mendalam mengenai literasi digital khususnya pada penyuluh pertanian karena penelitian ini masih jarang dan sangat dibutuhkan data mengenai tingkat literasi digital penyuluh pertanian. Penelitian yang akan mendatang diharapkan menggunakan sampel yang lebih banyak sehingga hasil dari analisis ini lebih akurat dan perlu ditambahkannya variabel lain yang memengaruhi perilaku pencarian informasi oleh penyuluh di internet selain variabel yang telah diteliti.

\section{DAFTAR PUSTAKA}

APJII. (2018). Penetrasi \& Profil Perilaku Pengguna Internet Indonesia. https://apjii.or.id/survei2018s/download/TK5oJYBSyd8iqHA2eCh4FsGELm3ubj

Aprilla, D. (2017). Perilaku Pencarian Informasi Penyuluh Perikanan Untuk Memenuhi Kebutuhan Informasi Petani Tambak di Kecamatan Padang Gelugur Pasaman. UIN Imam Bonjol Padang.

Arikunto, S. (2002). Prosedur Penelitian: Suatu Pendekatan Praktek. Rineka Cipta.

Bahua, M. I., Jahi, A., Asngari, P. S., Saleh, A., \& Purnaba, G. P. (2010). Faktor-Faktor yang Mempengaruhi Kinerja Penyuluh Pertanian dan Dampaknya pada Perilaku Petani Jagung Di Provinsi Gorontalo. Jurnal Ilmiah Agropolitan, 3(1), 293-303.

Budhyani. (2008). Potensi Perajin Wanita dalam Pengembangan Kerajinan Uang Kepeng di Kawasan Pariwisata Ubud Bali. Jurnal Penelitian Dan Pengembangan Sains Dan Humaniora, $2(1), 43-45$.

Dinpanah, G., \& Lashgarara, F. (2011). Factors Influencing the Information Seeking Knowledge of wheat farmers in Iran. African Journal of Agricultural Research, 6(14), 3419-3427. https://doi.org/10.5897/AJAR11.164

Eisenberg, M. B. (2008). Information Literacy: Essential Skills for the Information Age. DESIDOC Journal of Library \& Information Technology, 28(2), 39-47. https://doi.org/10.14429/djlit.28.2.166

Ellis, D., Cox, D., \& Hall, K. (1993). A comparison of the information seeking patterns of researchers in the physical and social sciences. Journal of Documentation, 49(4), 356-369. https://doi.org/10.1108/eb026919

Gani, I., \& Amalia, S. (2015). Alat Analisis Data: Aplikasi Statistik untuk Penelitian Bidang Ekonomi dan Sosial. Andi.

Ghozali, I. (2001). Aplikasi Analisis Multivariate dengan Program SPSS. Badan Peneliti Universitas Diponegoro.

Gilster, P. (1997). Digital Literacy. Wiley Computer Pub.

Hafidhah, N. (2020). Pengaruh Literasi Digital Terhadap Perilaku Pencarian Informasi Mahasiswa Universitas Islam Negeri Ar-Raniry Banda Aceh Angkatan 2016. UIN Ar-Raniry Banda Aceh.

Hussein, H. (2019). Effect of Digital Literacy on Information Seeking Behaviour Among Managers of Telecommunication Companies in Saudi Arabia. International Journal of Library and Information Science, 8(2), 1-8. https://doi.org/10.34218/ijlis.8.2.2019.001

Juliansyah. (2013). Penelitian Ilmu Manajemen: Tinjauan Filosofis dan Praktis. Kencana.

Kuncel, N. R., Hezlett, S. A., \& Ones, D. S. (2004). Academic Performance, Career Potential, Creativity, and Job Performance: Can One Construct Predict Them All? In Journal of 
Personality and Social Psychology (Vol. 86, Issue 1, pp. 148-161). American Psychological Association. https://doi.org/10.1037/0022-3514.86.1.148

Latan, H., \& Temalagi, S. (2013). Analisis Multivariate Teknik dan Aplikasi Menggunakan Program IBM SPSS 20. Alfabeta.

Mardikanto. (2010). Penyuluhan Pembangunan Pertanian. Universitas Sebelas Maret.

Matindas, K., Hubeis, A., Suwardi, H., \& Saleh, A. (2013). Selektivitas Dan Penilaian Kualitas Informasi Pertanian Dalam Perspektif Gender. Jurnal Studi Komunikasi Dan Media, 15(1), 119. https://doi.org/10.31445/jskm.2011.150104

Okwu, O. J., \& Umoru, B. I. (2009). A study of women farmers' agricultural information needs and accessibility: A case study of Apa local government area of Benue State, Nigeria. African Journal of Agricultural Research, 4(12), 1404-1409.

Rasmira, Lubis, D. P., \& Gandasari, D. (2019). Literasi Informasi Penyuluh Pertanian di Kabupaten Cianjur Information Literacy among Extension Workers in Cianjur Regency. Jurnal Penyuluhan, 15(2), 254-265.

Singarimbun, \& Efendi. (2008). Metode Penelitian Survei. LP3ES.

Singh, M. (2018). Digital Literacy: an Essential Life Skill In the Present Era of Growing and Global Educational Society. Journal of Advances and Scholarly Researches in Allied Education, 15(8), 62-67. https://doi.org/10.29070/15/57868

Siregar, S. (2014). Statistik Parametrik untuk penelitian Kuantitatif. Bumi Aksara.

Slamet. (1992). Perspektif Ilmu Penyuluhan Pembangunan Menyongsong Era Tinggal Landas. Pustaka Pembangunan Swadaya.

Springer, M. V., McIntosh, A. R., Winocur, G., \& Grady, C. L. (2005). The relation between brain activity during memory tasks and years of education in young and older adults. Neuropsychology, 19(2), 181-192. https://doi.org/10.1037/0894-4105.19.2.181

Sugiyono. (2013). Metode Penelitian Kuantitatif, Kualitatif, dan R\&D. Alfabeta.

Suhanda, N. S., Jahi, A., Sugihen, B. G., \& Susanto, D. (2008). Kinerja Penyuluh Pertanian di Jawa Barat. Jurnal Penyuluhan, 4(2), 101-107. https://doi.org/10.25015/penyuluhan.v4i2.2175

Suhardiyono. (1992). Penyuluhan: Petunjuk bagi Penyuluh Pertanian. Erlangga.

Sulaeman, A. (2014). Pengaruh Upah Dan Pengalaman Kerja terhadap Produktivitas Karyawan Kerajinan Ukiran Kabupaten Subang. Trikonomika, 13(1), 91-100.

Tamba, M., \& Sarma, M. (2007). Faktor-Faktor Yang Mempengaruhi Kebutuhan Informasi Pertanian Bagi Petani Sayuran Di Provinsi Jawa Barat. Jurnal Penyuluhan, 3(1), 24-33. https://doi.org/10.25015/penyuluhan.v3i1.2148

Utomo. (2009). Preparedness Assesment Tools for Indonesia. HFI.

Wijaya, A. S., Sarwoprasodjo, S., \& Febrina, D. (2019). Cyber Extension: Penggunaan Media dan Kelancaran Pencarian Informasi di Kalangan Penyuluh Pertanian Kabupaten Bogor. Jurnal KMP (Jurnal Komunikasi Pembangunan), 17(2), 114-123. https://doi.org/10.29244/jurnalkmp.17.2.114-123

Yusup. (2013). Ilmu Informasi dan Kepustakaan. Bumi aksara. 